\title{
Anti-interleukin-6 therapy for treatment of high platelet counts in cGMP-dependent protein kinase I gene-targeted mice
}

\author{
Lin Zhang ${ }^{1}$, Robert Lukowski ${ }^{2,3^{*}}$, Florian Gaertner ${ }^{1}$, Michael Lorenz ${ }^{1}$, Kyle R Legate ${ }^{1,4}$, Katrin Domes ${ }^{2}$, \\ Elisabeth Angermeier ${ }^{2}$, Franz Hofmann², Steffen Massberg ${ }^{1,2}$ \\ From 6th International Conference on cGMP: Generators, Effectors and Therapeutic Implications \\ Erfurt, Germany. 28-30 June 2013
}

\section{Background}

The cyclic guanosine-3',5'-monophosphate (cGMP)/ cGMP-dependent protein kinase type I (cGKI) pathway is a potent negative regulator of platelet adhesion and aggregation [1]; however, the role of cGMP/cGKI for platelet biogenesis in vivo is unclear.

\section{Results}

Here we report thrombocytosis in conventional cGKI null mutants $\left(\mathrm{cGKI}^{\mathrm{L} 1 / \mathrm{L} 1}\right)$ and gene-targeted cGKI $\alpha / \beta$ rescue mice (referred to as cGKI-SM) with cGKI expression specifically restored in smooth muscle (SM), but not in other cell types [2-4]. In contrast, conditional knockouts lacking the cGKI protein specifically in the megakaryocyte $(\mathrm{MK}) /$ platelet lineage (Pf4-Cre ${ }^{\mathrm{tg} /+}$; $\mathrm{cGKI}^{\mathrm{L} 2 / \mathrm{L} 2}$ ) did not display a related thrombocytosis phenotype, indicating that the high platelet count of $\mathrm{cGKI}^{\mathrm{L} 1 / \mathrm{L} 1}$ and cGKI-SM mutants is rather a reactive response than an intrinsic defect in megakaryopoiesis. In line with these findings, wild-type (WT) mice engrafted with cGKI-deficient bone-marrow (BM) cells showed full reconstitution of haematopoiesis and normal platelet counts upon myeloablative radiotherapy. Stimulation of BM-derived WT MKs using serum preparations from cGKI-SM mutants strongly accelerated megakaryopoiesis, suggesting that their high platelet counts develop in response to soluble factors. Indeed, we confirm elevated Interleukin-6 (IL-6) serum levels [5,6], a known cause for reactive thrombocytosis, in cGKI-SM mutants, whereas IL-6 was unaltered in Pf4-Cre ${ }^{\mathrm{tg} /+}$; cGKI ${ }^{\mathrm{L} 2 / \mathrm{L} 2}$ mice and

\footnotetext{
* Correspondence: robert.lukowski@uni-tuebingen.de

${ }^{2}$ Forschergruppe 923, Institut für Pharmakologie und Toxikologie, Technische Universität München, München, Germany

Full list of author information is available at the end of the article
}

cGKI-deficient BM chimaeras. Vice versa, antibodymediated blockage of IL- 6 reduced platelet counts in cGKI-SM mice, but not in WT mice.

\section{Conclusion}

We conclude that abnormal signalling of cGMP/cGKI in non-hematopoietic cells affects thrombopoiesis via IL-6 resulting in a reactive thrombocytosis in vivo.

\section{Authors' details \\ 'Medizinische Klinik und Poliklinik I, Klinikum der Universität, Ludwig- Maximilians-Universität, München, Germany. ${ }^{2}$ Forschergruppe 923, Institut für Pharmakologie und Toxikologie, Technische Universität München, München, Germany. ${ }^{3}$ Pharmakologie, Toxikologie und Klinische Pharmazie, Institut für Pharmazie, Universität Tübingen, Tübingen, Germany. ${ }^{4}$ Center for NanoScience, Department of Applied Physics, Ludwig-Maximilians- Universität, München, München, Germany.}

Published: 29 August 2013

\section{References}

1. Massberg S, Sausbier M, Klatt P, Bauer M, Pfeifer A, Siess W, Fassler R, Ruth P, Krombach F, Hofmann F: Increased adhesion and aggregation of platelets lacking cyclic guanosine $3^{\prime}, 5^{\prime}$-monophosphate kinase I. J Expt Med 1999, 189:1255-1264.

2. Weber $S$, Bernhard $D$, Lukowski $R$, Weinmeister $P$, Worner R, Wegener JW, Valtcheva N, Feil S, Schlossmann J, Hofmann F, Feil R: Rescue of cGMP kinase I knockout mice by smooth muscle specific expression of either isozyme. Circ Res 2007, 101:1096-1103.

3. Lukowski R, Rybalkin SD, Loga F, Leiss V, Beavo JA, Hofmann F: Cardiac hypertrophy is not amplified by deletion of cGMP-dependent protein kinase I in cardiomyocytes. Proc Natl Acadf Sci USA 2010, 107:5646-5651.

4. Leiss V, Friebe A, Welling A, Hofmann F, Lukowski R: Cyclic GMP kinase I modulates glucagon release from pancreatic alpha-cells. Diabetes 2011, 60:148-156.

5. Lut SZZ, Hennige AM, Feil S, Peter A, Gerling A, Machann J, Krober SM, Rath M, Schurmann A, Weigert C, Haring HU, Feil R: Genetic ablation of cGMP-dependent protein kinase type I causes liver inflammation and fasting hyperglycemia. Diabetes 2011, 60:1566-1576.

6. Mitschke MM, Hoffmann LS, Gnad T, Scholz D, Kruithoff K, Mayer P, Haas B, Sassmann A, Pfeifer A, Kilic A: Increased cGMP promotes healthy 
expansion and browning of white adipose tissue. FASEB J 2013, 27:1621-1630

doi:10.1186/2050-6511-14-S1-P80

Cite this article as: Zhang et al:: Anti-interleukin- 6 therapy for treatment

of high platelet counts in CGMP-dependent protein kinase I gene-

targeted mice. BMC Pharmacology and Toxicology 2013 14(Suppl 1):P80.

Submit your next manuscript to BioMed Central and take full advantage of:

- Convenient online submission

- Thorough peer review

- No space constraints or color figure charges

- Immediate publication on acceptance

- Inclusion in PubMed, CAS, Scopus and Google Scholar

- Research which is freely available for redistribution

Submit your manuscript at 